Corresponding Member of the NAPS of Ukraine, $\mathrm{PhD}$ in Pedagogical Sciences, Full Professor, OLEH PADALKA National Pedagogical Dragomanov University, Ukraine Address: 9 Pyrogova St., Kyiv, 01601, Ukraine E-mail: shef-npu@ukr.net $\mathrm{PhD}$ in Pedagogical Sciences, OLEKSANDR VORONENKO Ministry of Education and Science of Ukraine Address: 10 Peremogy Ave, Kyiv, 01135, Ukraine E-mail: a_voronenko@mon.gov.ua $\mathrm{PhD}$ in Pedagogical Sciences, Associate Professor, TETIANA HUMENIUK National Pedagogical Dragomanov University, Ukraine Address: 9 Pyrogova St., Kyiv, 01601, Ukraine E-mail: Gumenyuktb@ukr.net

\title{
MODERN GUIDELINES FOR FORMING THE INTERNATIONAL IMAGE OF UNIVERSITIES: FOREIGN EXPERIENCE
}

\begin{abstract}
The article presents the analysis of scientific and technological activities of higher education pedagogical institutions of Ukraine at the end of 2014 according to the staffing situation, the functioning of postgraduate and doctoral studies and the availability of the valid specialized academic councils on thesis defense, according to students' research works aiming at young scientists' training. The criteria of evaluation of scientific work results of the university faculty and the ways to encourage young teachers to do the research work through postgraduate and doctoral studies and the defense of the thesis as the final result. We raised a problem of training young scientists int higher education pedagogical institutions of Ukraine as a powerful intellectual force, which determines the scientific future of the country. The main directions of scientific and technical activities of the universities aimed at foreign cooperation within the country and the world were defined as well. Modern guidelines for forming the international image of universities in foreign experience (the USA and European countries) have been outlined.
\end{abstract}

Key words: scientific activity, faculty, higher pedagogical educational institution, criteria for evaluation of scientific work results, postgraduate studies, doctoral studies, scientific potential, young scientists, students' research work.

\section{INTRODUCTION}

At the Conference of Nobel Laureates "Facing the twenty first century: threats and promises" held in Paris in 1998, education was defined as an absolute priority of human development, which stated that "Education should be an absolute priority in the budgets of all countries and should promote the development of all creative activities". This statement can be taken as an axiom because the decisive factors for today's socio-economic development are the human capital, the intellectual resource, expressed in the knowledge, culture and spirituality of the entire world community, which is practically boundless, inexhaustible and constantly reproducible (Дарійчук, 2014).

So, it is obvious that pedagogical education acquires particular importance among all spheres of education aiming at training teachers. The main task of the modern educator 
is the forming of the younger generation of citizens capable of a systematic approach to addressing the most vital issues and project thinking in the world of continuous innovation. This requires higher pedagogical educational institutions to have a high level of future professionals' training, and besides that, they should be in the vanguard of science, scientific and technical activities aimed at providing creative development to the faculty and young scientists including future practicing teachers and teacher-scholars.

\section{THE AIM OF THE STUDY}

The aim of the article is to highlight the results of the scientific activities of the faculty in Ukraine and outline modern guidelines for forming the international image of universities in the USA and European countries.

\section{THEORETICAL FRAMEWORK AND RESEARCH METHODS}

It has been investigated in the course of study that the problems of secondary education teaching staff training have been studied by A. Borovik, V. Grinyova, V. Krichevsky, V. Lozova, Yu. Vasilyev and others. The historical development of the education system in the early XX century was investigated in the works of N. Agafonov, V. Lypynsky, M. Marchuk and others. The content of scientific and educational activities of university lecturers was studied by I. Dmitriev, E. Klementiev, S. Lebedev, V. Pugach, V. Tonkal, Z. Yesaryeva, and others.

In the process of research we used scientific methods of analysis, comparison, systematization and synthesis of informational material on scientific activity in higher education pedagogical institutions of Ukraine.

\section{RESULTS}

The effectiveness of modern higher pedagogical institution largely depends on the qualification level and individual creative skills of its faculty that is why the university research and teaching staff is regarded as the most significant part of its assets.

There is an ongoing campaign aimed at increasing the level of professionalism and scholarship and attracting leading experts and reputable scientists to the educational activities in higher institutions of Ukraine. The overall picture of this process at the end of 2014 is highlighted in the summary personnel (see Table 1).

The constant interaction of scientific and pedagogical activity of the higher education institution and a teacher is the main feature of this activity (Пугач, 2010; Можаева, 2009; Дмитриева, 2008).

In order to increase the degree of impact of scientific potential usage of the faculty the higher education pedagogical institutions face the problem of finding effective methods of encouraging them to creative activity. In this context, first of all, we should define the basic criteria for the scientific results of professors, associate professors, senior lecturers and assistants of the universities of the accreditation levels III-IV, relying on the relevant regulations on implementing the Law of Ukraine "On Education" (Закон України «Про вищу освіту», 2014).

They typically include: the scientific potential quality indicator - the scientific degree; the number of the trained Candidates of Sciences (formally supervised theses); the number of the issued textbooks and monographs (considering their volume); the number of articles published in scientific and technical journals and digests; the number of the published scientific articles and theses in collaboration with students; the number of the trained winners of the students competitions (with the required differentiation for the first three places); the number of students research works competition awards; the number of governmental awards (laureates, competition winners etc.); the number of the received patents. 
Summary Personnel Table in Higher Education Pedagogical Institutions according to the Database at the End of 2014

\begin{tabular}{|c|c|c|c|c|c|c|c|c|c|c|c|c|c|}
\hline $\begin{array}{l}\text { Education } \\
\text { institution }\end{array}$ & 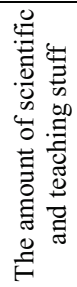 & 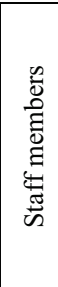 & 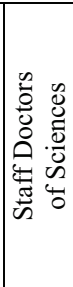 & 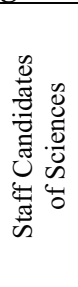 & 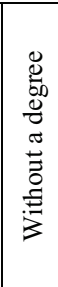 & 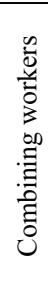 & 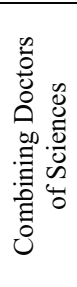 & 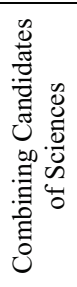 & 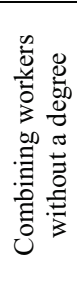 & 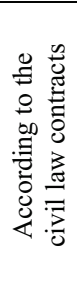 & 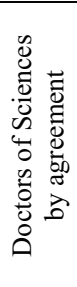 & 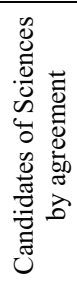 & 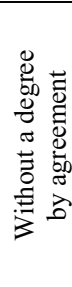 \\
\hline 1 & 2 & 3 & 4 & 5 & 6 & 7 & 8 & 9 & 10 & 11 & 12 & 13 & 14 \\
\hline \begin{tabular}{|c|} 
Oleksandr \\
Dovzhenko \\
Hlukhiv National \\
Pedagogical \\
University, HSEE \\
"Donbass State \\
Pedagogical \\
University"
\end{tabular} & 286 & 206 & 18 & 106 & 82 & 80 & 15 & 37 & 28 & 0 & 0 & 0 & 0 \\
\hline \begin{tabular}{|c|} 
Berdyansk State \\
Pedagogical \\
University
\end{tabular} & 327 & 316 & 31 & 197 & 88 & 11 & 4 & 5 & 2 & 0 & 0 & 0 & 0 \\
\hline $\begin{array}{c}\text { HSEE "Donbass } \\
\text { State Pedagogical } \\
\text { University" }\end{array}$ & 354 & 352 & 24 & 231 & 97 & 2 & 1 & 1 & 0 & 0 & 0 & 0 & 0 \\
\hline \begin{tabular}{|c|} 
Melitopol State \\
Pedagogical \\
University named \\
after Bohdan \\
Khmelnytskyi \\
\end{tabular} & 386 & 332 & 28 & 190 & 114 & 34 & 10 & 10 & 14 & 20 & 4 & 8 & 8 \\
\hline \begin{tabular}{|c|} 
HSEE "Hryhorii \\
Skovoroda \\
Pereiaslav- \\
Khmelnytskyi \\
State Pedagogical \\
University"
\end{tabular} & 401 & 345 & 28 & 200 & 117 & 56 & 32 & 18 & 6 & 0 & 0 & 0 & 0 \\
\hline \begin{tabular}{|c|} 
The Kirovohrad \\
Volodymyr \\
Vynnychenko \\
State Pedagogical \\
University
\end{tabular} & 412 & 383 & 26 & 289 & 68 & 29 & 9 & 8 & 12 & 0 & 0 & 0 & 0 \\
\hline \begin{tabular}{|c|} 
Vinnytsia State \\
Pedagogical \\
University named \\
after Mykhailo \\
Kotsiubynsky
\end{tabular} & 424 & 408 & 26 & 276 & 106 & 16 & 3 & 8 & 5 & 0 & 0 & 0 & 0 \\
\hline $\begin{array}{c}\text { Poltava } \\
\text { V. G. Korolenko } \\
\text { National } \\
\text { Pedagogical } \\
\text { University }\end{array}$ & 435 & 411 & 35 & 241 & 135 & 24 & 1 & 14 & 9 & 0 & 0 & 0 & 0 \\
\hline \begin{tabular}{|c|} 
Chernihiv \\
National \\
Pedagogical \\
University \\
named after \\
T. H. Shevchenko
\end{tabular} & 438 & 405 & 26 & 256 & 123 & 29 & 4 & 7 & 18 & 4 & 0 & 0 & 4 \\
\hline
\end{tabular}




\begin{tabular}{|c|c|c|c|c|c|c|c|c|c|c|c|c|c|}
\hline & & & & & & & & & & & & \multicolumn{2}{|c|}{ Continuea } \\
\hline 1 & 2 & 3 & 4 & 5 & 6 & 7 & 8 & 9 & 10 & 11 & 12 & 13 & 14 \\
\hline \begin{tabular}{|l|} 
South Ukrainian \\
National \\
Pedagogical \\
University \\
named after \\
K. D. Ushynsky \\
\end{tabular} & 481 & 458 & 61 & 276 & 121 & 23 & 5 & 10 & 8 & 0 & 0 & 0 & 0 \\
\hline $\begin{array}{c}\text { Sumy State } \\
\text { Pedagogical } \\
\text { University } \\
\text { named after } \\
\text { A. S. Makarenko }\end{array}$ & 485 & 443 & 23 & 220 & 200 & 32 & 5 & 12 & 15 & 10 & 0 & 5 & 5 \\
\hline $\begin{array}{c}\text { Ternopil } \\
\text { Volodymyr } \\
\text { Hnatyuk National } \\
\text { Pedagogical } \\
\text { University }\end{array}$ & 542 & 487 & 52 & 343 & 92 & 55 & 3 & 16 & 36 & 0 & 0 & 0 & 0 \\
\hline $\begin{array}{l}\text { Pavlo Tychyna } \\
\text { Uman State } \\
\text { Pedagogical } \\
\text { University }\end{array}$ & 570 & 471 & 30 & 243 & 198 & 99 & 18 & 22 & 59 & 0 & 0 & 0 & 0 \\
\hline $\begin{array}{c}\text { Drohobych } \\
\text { Ivan Franko State } \\
\text { Pedagogical } \\
\text { University }\end{array}$ & 662 & 620 & 46 & 310 & 264 & 42 & 14 & 18 & 10 & 0 & 0 & 0 & 0 \\
\hline $\begin{array}{c}\text { H. S. Skovoroda } \\
\text { Kharkiv National } \\
\text { Pedagogical } \\
\text { University }\end{array}$ & 829 & 786 & 74 & 432 & 280 & 43 & 4 & 21 & 18 & 0 & 0 & 0 & 0 \\
\hline $\begin{array}{c}\text { National } \\
\text { Pedagogical } \\
\text { Dragomanov } \\
\text { University }\end{array}$ & 1942 & 1338 & 187 & 659 & 492 & 300 & 116 & 145 & 39 & 304 & 47 & 153 & 104 \\
\hline
\end{tabular}

The list of criteria may be extended by such university decisions as acting as opponents for dissertations in the specialized councils during the theses defense, in the editorial boards of the scientific and technical publications, the number of the ready dissertation abstracts reviews. This is the additional system of scientific activity of the university faculty results evaluation criteria that enhances its image and rating in Ukraine and the world.

One of the most effective ways to encourage young teachers to the research work is to attract them to postgraduate and doctoral studies. According to the Regulation on the training of scientific and pedagogical staff (Положення про підготовку науковопедагогічних і наукових кадрів, 1999) postgraduate and doctoral studies are forms of training scientific-pedagogical and scientific personnel of higher qualification and functions solely at those higher education institutions of accreditation levels III-IV, which have highly-qualified, educational and scientific personnel, modern scientific, experimental and material resources. The effective result of postgraduate and doctoral studies should be the defense of the candidate or doctoral thesis. So, specialized academic councils are open and successfully operate in most higher education pedagogical institutions (Мережа спеціалізованих вчених рад, 2014) (see Table 2).

Young scientists are a powerful intellectual force that builds the scientific future of the country and actively influences the formation of socio-economic and political development of the country (Міністерство освіти і науки України, 2014). 
The Summary Table of the Specialized Academic Councils and the Defended Theses

in Higher Education Pedagogical Institutions according to the Database of 2014

\begin{tabular}{|c|c|c|c|}
\hline Education institution & $\begin{array}{c}\text { The amount of specialized } \\
\text { academic councils } \\
\text { for the theses defense }\end{array}$ & $\begin{array}{l}\text { The amount of specialized } \\
\text { academic councils for the } \\
\text { doctoral theses defense }\end{array}$ & $\begin{array}{c}\text { The total amount } \\
\text { of defended } \\
\text { theses }\end{array}$ \\
\hline $\begin{array}{l}\text { National Pedagogical Dragomanov } \\
\text { University }\end{array}$ & 3 & 3 & 147 \\
\hline $\begin{array}{l}\text { H. S. Skovoroda Kharkiv National } \\
\text { Pedagogical University }\end{array}$ & 1 & 0 & 101 \\
\hline $\begin{array}{l}\text { South Ukrainian National Pedagogical } \\
\text { University named after K. D. Ushynsky }\end{array}$ & 0 & 0 & 57 \\
\hline $\begin{array}{l}\text { HSEE "Hryhorii Skovoroda } \\
\text { Pereiaslav-Khmelnytskyi } \\
\text { State Pedagogical University" }\end{array}$ & 1 & 0 & 44 \\
\hline $\begin{array}{l}\text { Pavlo Tychyna Uman State } \\
\text { Pedagogical University }\end{array}$ & 0 & 0 & 42 \\
\hline $\begin{array}{l}\text { Ternopil Volodymyr Hnatyuk } \\
\text { National Pedagogical University }\end{array}$ & 1 & 0 & 40 \\
\hline $\begin{array}{l}\text { Kirovohrad Volodymyr Vynnychenko } \\
\text { State Pedagogical University }\end{array}$ & 1 & 0 & 34 \\
\hline $\begin{array}{l}\text { Vinnytsia State Pedagogical University } \\
\text { named after Mykhailo Kotsiubynsky }\end{array}$ & 0 & 0 & 25 \\
\hline $\begin{array}{l}\text { HSEE "Donbass State Pedagogical } \\
\text { University" }\end{array}$ & 1 & 0 & 24 \\
\hline $\begin{array}{l}\text { Chernihiv National Pedagogical } \\
\text { University named after T. H. Shevchenko }\end{array}$ & 0 & 1 & 21 \\
\hline $\begin{array}{l}\text { Drohobych Ivan Franko } \\
\text { State Pedagogical University }\end{array}$ & 0 & 0 & 21 \\
\hline $\begin{array}{l}\text { Melitopol State Pedagogical University } \\
\text { named after Bohdan Khmelnytsky }\end{array}$ & 1 & 0 & 20 \\
\hline $\begin{array}{l}\text { Berdyansk State Pedagogical } \\
\text { University }\end{array}$ & 0 & 1 & 14 \\
\hline $\begin{array}{l}\text { Oleksandr Dovzhenko Hlukhiv } \\
\text { National Pedagogical University }\end{array}$ & 1 & 0 & 8 \\
\hline $\begin{array}{l}\text { Poltava V. G. Korolenko National } \\
\text { Pedagogical University }\end{array}$ & 0 & 0 & 5 \\
\hline $\begin{array}{l}\text { Sumy State Pedagogical University } \\
\text { named after A. S. Makarenko }\end{array}$ & 0 & 0 & 5 \\
\hline
\end{tabular}

Nowadays, the Ministry of Education and Science of Ukraine actively supports young researchers, namely, it promotes the interaction of MESU with self-governing youth organizations of scientific research institutions and higher education institutions of Ukraine; participates in the forming of motions on legal, social and economic conditions to attract talented young people to work in the scientific field, strongly stimulates the professional activity of young scientists in the national research institutions and universities, supports the process of rising their professional level and the realization of their creative and professional activity; provides young scientists with advisory support in matters of research activities, supports collaboration with foreign customers of the research products, helps to attract young scientists to participate in scientific works competitions, to form groups of young scientists aimed at performing the advanced research projects.

Higher education pedagogical institutions are actively involved in the process of fusion of the future scientific educational potential. The results of the research activity of students, which indicate the activation of Scientific Research Students' Work in 2014 are shown below (see Table 3). 
The Summary Table of the Research Students' Work

in Higher Education Pedagogical Institutions according to the Database of 2014

\begin{tabular}{|c|c|c|c|c|}
\hline $\begin{array}{l}\text { Education } \\
\text { institution }\end{array}$ & $\begin{array}{c}\text { The number } \\
\text { of students } \\
\text { who } \\
\text { participate in } \\
\text { research work }\end{array}$ & $\begin{array}{c}\text { The } \\
\text { percentage } \\
\text { of young } \\
\text { scientists } \\
\text { among all } \\
\text { students }\end{array}$ & $\begin{array}{c}\text { Number of young } \\
\text { scholars who stayed } \\
\text { at the university after } \\
\text { finishing their } \\
\text { studies } \\
\text { (employees, } \\
\text { postgraduates) }\end{array}$ & $\begin{array}{c}\text { The percentage } \\
\text { of young scholars } \\
\text { who stayed at the } \\
\text { university after } \\
\text { finishing their } \\
\text { studies } \\
\text { (employees, } \\
\text { postgraduates) }\end{array}$ \\
\hline National Pedagogical Dragomanov University & 5189 & 56 & 865 & 28 \\
\hline $\begin{array}{l}\text { H.S. Skovoroda Kharkiv National } \\
\text { Pedagogical University }\end{array}$ & 4250 & 73,7 & 345 & 63 \\
\hline \begin{tabular}{|l|} 
South Ukrainian National Pedagogical \\
University named after K. D. Ushynsky
\end{tabular} & 2733 & 93 & 225 & 22 \\
\hline $\begin{array}{l}\text { Drohobych Ivan Franko State Pedagogical } \\
\text { University }\end{array}$ & 2697 & 81,4 & 217 & 84,6 \\
\hline $\begin{array}{l}\text { Pavlo Tychyna Uman State Pedagogical } \\
\text { University }\end{array}$ & 2644 & 55 & 198 & 88 \\
\hline $\begin{array}{l}\text { Vinnytsia State Pedagogical University } \\
\text { named after Mykhailo Kotsiubynsky }\end{array}$ & 2531 & 41 & 195 & 46 \\
\hline $\begin{array}{l}\text { Ternopil Volodymyr Hnatyuk National } \\
\text { Pedagogical University }\end{array}$ & 2457 & 55,45 & 161 & 13 \\
\hline $\begin{array}{l}\text { HSEE "Donbass State Pedagogical } \\
\text { University" }\end{array}$ & 1671 & 86 & 127 & 50 \\
\hline $\begin{array}{l}\text { The Kirovohrad Volodymyr Vynnychenko } \\
\text { State Pedagogical University }\end{array}$ & 1483 & 30 & 127 & 41 \\
\hline $\begin{array}{l}\text { Chernihiv National Pedagogical University } \\
\text { named after T. H. Shevchenko }\end{array}$ & 1400 & 59 & 123 & 64,5 \\
\hline Berdyansk State Pedagogical University & 1874 & 79 & 110 & 100 \\
\hline $\begin{array}{l}\text { HSEE "Hryhorii Skovoroda Pereiaslav- } \\
\text { Khmelnytskyi State Pedagogical University", }\end{array}$ & 1768 & 71,2 & 104 & 52 \\
\hline $\begin{array}{l}\text { Oleksandr Dovzhenko Hlukhiv National } \\
\text { Pedagogical University }\end{array}$ & 1790 & 85 & 100 & 95 \\
\hline $\begin{array}{l}\begin{array}{l}\text { Poltava V.G. Korolenko National Pedagogical } \\
\text { University }\end{array} \\
\end{array}$ & 1470 & 52 & 91 & 49,2 \\
\hline $\begin{array}{l}\text { Melitopol State Pedagogical University } \\
\text { named after Bohdan Khmelnytsky }\end{array}$ & 1985 & 86,9 & 90 & 45,3 \\
\hline $\begin{array}{l}\text { Sumy State Pedagogical University } \\
\text { named after A. S. Makarenko }\end{array}$ & 2753 & 67,8 & 83 & 47,4 \\
\hline
\end{tabular}

Except the indicators of scientific activity in higher education pedagogical institutions the evaluation of results in this area is affected by the outstanding results of the basic research in the sphere of natural sciences, social sciences and humanities, including the world-class scientific achievements; the most important results of the applied research, the competitive applications and new technologies for the priority areas of science and technology; the applications introduced in 2014 outside the higher education institutions; the effectiveness of the structural unit of the commercialization of research and technical applications of the higher education institutions; the list of scientific papers published, edited and accepted for publication in 2014 in foreign journals that have an impact factor; the results of research subdivisions, their activity, work with customers (institutes, laboratories, centers of collective use of the latest equipment, technology transfer centers, etc.); scientific and technical cooperation with foreign organizations; the results of scientific and technological activities, carried out in cooperation with scientific institutions 
of the National Academy of Sciences of Ukraine and national specialized academies of sciences; measures taken in cooperation with the regional state administrations or the Kyiv City State Administration and aimed at improving the efficiency of scientists and addressing regional needs; the level informational support of scientific activity, the access to electronic collections of scientific periodicals and databases of the leading scientific publishers in the world about the patent and licensing activities; the results of research work carried out in the departments of universities within the teachers' working time; the dynamics of material and technical base of scientific research.

Nowadays, the globalization of business creates a need for experts and scientific research on the scale that goes beyond a single country. As a result of these tendencies, universities face the problem of training and production of scientific ideas that would be competitive in the world (The Times Higher Education, 2015). It has become a prerequisite of the universities ranking according to "Times" (The Times Higher Education, 2015), which establishes the universities' position depending on whether they are ranked as "world class universities". Forming the rating a high percentage belongs to the research work (30\% of the total evaluation of the university). Unfortunately, by the time of the ranking (2005), none of the Ukrainian higher education institutions was included to the list of the top world universities. So, nowadays, the integration of higher education of Ukraine into the global system is a process that will ensure the advancement of Ukrainian universities to a new level.

An awareness of the necessity to develop research and technological parks, technologies incubators at universities, which started to play the role of interface between the university and the economy and is designed to commercialize the results of the research, to bring them to the finished product and to transfer to the real economy has appeared in market relations.

The integration of universities, research organizations and high tech companies should ideally be integrated to combine all of the mentioned areas of common research, educational and innovational activity. Ultimately, it should be directed to the formation and development of certain industrial and economic cluster, which is a priority for the region and/or the industry.

Nowadays, foreign and domestic scientists pay constant attention to the problems of integration of science, education and production. Experience shows that when special training of students is conducted in close cooperation with research institutions, the professional guidance in these institutions immediately causes a change in the nature of knowledge that students receive. And despite the common problems and tasks the research segments of higher education institutions in developed countries are evolving according to somewhat different legal models of cooperation of research institutions and universities.

Obviously, the infrastructure can not be developed without the full scientific research development. Modern forms of collective investment into the scientific and technical activities of the universities, the participation in grant and research programs provide reasonable organizational, technical, informational support of the infrastructure of research that is particularly necessary for the universities in order to provide full participation of professors, graduate students and students in research, taking into account the diverse nature of the subjects of their research interests.

The issue of integration of science, education and production can be solved through a combination of a single complex of educational institutions of different levels, from school to professional training, as well as scientific and industrial structures. Such integration will enable us to use material and human resources more effectively, will provide a fast and 
flexible adaptation of vocational education system to the dynamics of the labour market and to implementation of major science and technology projects and programs.

The experience of the US universities, which are a kind of intellectual centers, where fundamental and applied research is closely connected with professional training, are of special interest in the development of the principles of combining the tasks of educational and scientific activity in the system of the universities. The state support of the research activities of universities in the USA is much higher than in other countries, and the degree of "the rational use" of intellectual activity results of the university staff in the USA is the highest in the world. Their research projects are receiving financial support from the federal government (Department of Defense, Department of Energy, Department of Health \& Human Services, Department of Agriculture, National Science Foundation, National Aeronautics \& Space Administration) in the form of grants and contracts on joint activity.

In accordance with the legislation the US universities have developed the normative documents which regulate the rules of the procedure of applying for research, determine their value and the results of licensing and the distribution of revenues. The politics of the universities in the research activity sphere is based on the principles and priorities laid down in the statutes of universities. The basic element of the policy is the university's ownership of the results of intellectual activity that emerged in the course of research.

American universities are characterized by steady offensive tactics in the competitive struggle and by flexible and sensible response to market needs. It does not only refer to the introduction of new disciplines and areas in accordance with the industry demand, but also to active conquest of scientific market segments, even if other countries were undeniable scientific leaders in these areas.

The competition for research funding in Europe is not as strong as in the American universities. The universities get institutional grants that cover both the costs for research and training activities and besides that the system establishes no differences for scientists engaged or planning to be engaged in scientific research.

In Europe the integration process into science and education includes two components: the formation of the community of the leading European universities on the basis defined by Magna Charta Universitatum and the association of the national systems of education and science into the European space with the same requirements, criteria and standards. The main aim of this process is the consolidation of the efforts of the scientific and educational community and European governments to significantly improve the competitiveness of the European system of sciences and higher education in global terms, and to enhance the role of this system in accelerating the innovative development of national economies.

Analyzing the features inherent to integration processes of education, science and industry in developed countries, we can define the following points: first of all, the leading role in the development of these processes in other countries belongs to the state, which does not only actively encourages them, but also creates the necessary economic and legal conditions; secondly, the great diversity of existing forms of integration, as a general trend, can define the commitment to building integrated structures according to the territorial and distributive principle, due to the emergence of qualitatively new opportunities related to information technologies and telecommunications.

The bilateral and multilateral scientific and educational cooperation between universities was widely developed in this direction, the exchange of academic staff, postgraduates, doctoral students and young scientists, including the assistance of the established programs 
by EU (COMETT, ERASMUS, LINGUA, SOCRATES etc.). In addition to this, the interaction with foreign regional and national organizations, funds and programs such as UNESCO, TEMPUS / TACIS, DAAD, the World Bank, the British Council, "Open Society" Institute (Soros Foundation) and others plays an important role in the systematic expansion of the relations between Ukrainian universities and their international partners.

\section{CONCLUSIONS}

Considerable attention has recently been paid to the research, scientific and technological activities as they are the main condition of providing innovative and creative educational process in pedagogical education in Ukraine. In particular, the research activity of professors and young scientists plays an important role in this process. The highlighted results of analysis of scientific activity in higher educational institutions at the end of 2014 indicate a positive dynamics in this issue. However, positivr aspects of leading countries in forming the international image of universities should be taken into account.

Our further research will be focused on the analysis of the equally important component part - the content and results of scientific and technical activity of higher pedagogical education institutions aimed at foreign cooperation and enhancing the image of the institution at the state level and in the world.

\section{REFERENCES}

1. Times Higher Education. (2015). World Universities Rankings. Retrived 19.11.2015 from : http://www.timeshighereducation.co.uk/world-university-rankings/.

2. Дарійчук, Л. (2014). Система освіти в Україні: реформування чи оновлення? [Education System in Ukraine: Reform or rENEWAl?]. Вища школа [Higher school], No 1, pp. 40-52 (in Ukrainian).

3. Дмитриева, И. (2008). Трудовой договор научно-педагогических работников вузов [The Employment Contract of Scientific and Pedagogical Staff at the Universities: Monograph]. М. : Изд-во МГУ, 210 p. (in Russian).

4. Закон України «Про вищу освіту» [Law of Ukraine “On Higher Education”]. (2014). Retrieved 19.11.2015 from : http://zakon3.rada.gov.ua/laws/show/1556-18.

5. Мережа спеціалізованих вчених рад [The Network of Specialized Scientific Councils]. (2014). Retrieved 19.11.2015 from : http://old.mon.gov.ua/ua/activity/563/merezhaspetsializovanikh-vchenikh-rad.

6. Можаева, Л. (2009). Научно-технический прогресс и проблемы высшей школь (Страньл Северной Европь) [Scientific and Technological Progress and the Problems of Higher School (Nordic): Abstract Collection]. М. : ИНИОН РАН, 103 p. (in Russian).

7. Наказ Міністерства освіти і науки України «Про деякі питання діяльності Ради молодих учених» [The Ministry of Education and Science of Ukraine «On some Issues of the Council of Young Scientists]. (2014). Retrieved 19.11.2015 from : http://old. mon.gov.ua/ua/pr-viddil/1419922363/1419922456/.

8. Положення про підготовку науково-педагогічних $i$ наукових кадрів ["Regulations on Training Scientific-Pedagogical and Scientific-Research Specialists"]. (1999). Retrieved 19.11.2015 from : http://zakon5.rada.gov.ua/laws/show/309-99-\%D0\%BF.

9. Пугач, В. (2010). Профессорско-преподавательский персонал государственных вузов России: тенденции социокультурного развития в постсоветский период [Teaching Staff of State Universities in Russia: Trends of Social and Cultural Development in the Post-Soviet Period]. Alma Mater, No 7, pp. 24-37 (in Russian). 